\title{
Students' Learning Strategies in English Speaking Class
}

\author{
Prof. NONNY BASALAMA, MA., Ph. D. \\ nonnybasalama@gmail.com \\ Universitas Negeri Gorontalo \\ INDRI WIRAHMI BAY, S.Pd., MA. \\ indri_wirahmi@yahoo.com \\ Universitas Negeri Gorontalo \\ APRILIA ABUBAKAR \\ aprilia_abubakar@yahoo.com \\ Universitas Negeri Gorontalo
}

\begin{abstract}
Speaking is the most essential skill that must be learned in acquiring a new language. It is important for the students to find the best learning strategies in order help them in learning the materials. However, it is necessary for the students to realize that there are many kinds of learning strategies that they may use during English speaking class. Therefore, this study aimed to elaborate on the kinds of students' learning strategies in the English speaking class and to identify the factors that caused students to choose that learning strategy. The participants of this research were the students of English Department in the fourth semesters. The data were collected by using questionnaire and interview. The result shows that the students of English Department applied almost the learning strategies which provide on the metacognitive, cognitive, and socio-affective strategies while learning speaking. The most strategy used by students was note taking $(51,4 \%)$ and the least strategy was a translation $(19,6 \%)$. On the other hand, the strategy used by male students was cooperation $(16,8 \%)$ and there were $(27,1)$ female students who used self-evaluation as their strategy in learning speaking. Those learning strategies may be chosen depending on the students' occasion and learning objectives.
\end{abstract}

Keywords: Learning strategies, speaking, student

\section{INTRODUCTION}

English as the international language of many countries must be learned by many people, especially in the education aspect. In Indonesia, English is used as a foreign language, which means that English is not the primary language for daily interaction, and it is used restrictedly. In learning English, the students are demanded to master four skills of English, which are reading, writing, listening, and speaking. However, the students who learn English have experienced some difficulties during the learning process, particularly speaking skills.

In addition, among the four language skills, speaking is one of the important skills that must be learned in acquiring a new language. In the current time, speaking is utilized for many purposes, such as communication for daily life and academic context. Speaking 
for everyday communication is an activity that involves speaking as the main role to interact with other people or just to share the information in order to maintain someone's social life. Whereas, speaking for academics is more complex because it is utilized for a particular purpose, such as to persuade, to give proper information, to demonstrate things, and so forth in the academic context. Moreover, speaking is communication between some people to share their ideas and feeling. In addition, speaking in oral communication is used between speakers and listeners in order to transfer information, ideas, and feelings (Brown, 2003). Therefore, it can be pointed out that speaking is an oral skill which shows the speakers capability in constructing a systematic speech in order to show and express their thought by using the language.

As a matter of fact, the students faced some obstacles in learning English, especially speaking. However, every student has their own ways to catch and understand the lesson. Therefore, it is necessary for the students to discover several ideas to help them in learning English speaking. One of the ideas is by finding an appropriate learning strategy.

Learning strategies are the student's effort to accomplish a learning goal. According to Rubin (1975), learning strategies are a device used by the students to acquire knowledge. It means that the students can have one or more certain strategies to assist them in acquiring the knowledge that they want to learn. Moreover, O'Malley and Chamot (1990) point out that there are three kinds of learning strategies that the students can use, they are metacognitive strategies, cognitive strategies, and socio-affective strategies. Furthermore, the knowledge of students' learning strategies can make the differences between their success and failure in learning the task.

Several researchers have conducted studies regarding the learning strategies in speaking skills. First, Askia, Manurung, and Wahyudin (2015) have conducted research about improving students' speaking skills through active learning strategy in junior high school. On their research, they found that the students still less comprehensibility in understanding the meaning of the words and being passive in speaking class. In order to solve those problems, active learning strategies were applied by applying game in small group discussions in order to gain the students' fluent and their interest so that they will not be bored in the learning process. Another research was conducted by Juwita, Sukirlan, and Kadaryanto (2016) about the correlation between students' learning strategies and their speaking skills at high school. The result of their research shows that learning strategies are effective to help the students in improving their speaking performance.

Considering the two previous kinds of research above, those researches are only focused on the students of senior high school. However, there are still limited studies in English Department of the State University of Gorontalo that investigate the learning strategies used by university students in academic speaking. Thus, it becomes the main reason for the researcher to conduct a study in English Department Students related to the learning strategies in academic speaking.

Academic speaking is a skill that should be master by university students who enroll in English education at a university in order to be an English teacher. It is because of the importance of students' ability to be able to speak and present the material in higher level topics, involving analysis, critical thinking, and interpretation of the issue. Therefore, it is being an important thing for the students to find out the learning strategies to support them in presenting the material related to academic speaking. 
Based on the explanation above, this research tried to answer these research questions, as follows:

1. What kind of learning strategies do the students use in speaking for academic class?

2. What are the factors that caused the students to choose that learning strategy?

\section{THEORETICAL FRAMEWORK \\ LEARNING STRATEGIES}

Learning strategies are a device used by students to acquire knowledge (Rubin, 1975). Furthermore, Rigney (1978) illustrated that learning strategy as cognitive strategies that compromise certain operations and procedures. He continued that the students use those operations and procedures in order to acquire, retain, and retrieve different kinds of knowledge and performance. In line with him, Oxford (1990) described learning strategies as some steps taken by students to enhance their own learning. Then she proposed a more specific definition of learning strategies which is as specific actions taken by the students to make their learning easier, faster, more enjoyable, more self-directed, more effective, and more transferable to new situations.

Every person has their own learning strategies to help them in acquiring knowledge. Every strategy should be neatly arranged in order to help students improve their skills. Reid (2005) defined that learning strategy is a process of how the students manage learning. She continues that the students require a learning strategy to respond in an inefficient manner. Furthermore, strategies related to student's ability in applying a task. Thus, the knowledge of strategies determines success and failure in learning a task.

Drawing upon those definitions about learning strategies, it can be pointed out that learning strategies are some techniques or devices that may be used by the students in acquiring their knowledge related to their study. Furthermore, learning strategies are compromised by clear operations and procedures, in which it will assist and help the students with their learning activities before, during, and after the teaching and learning process that happens formally in the classroom.

\section{KINDS OF LEARNING STRATEGIES}

There are many ways for how students can apply learning strategies. Those learning strategies may be chosen depending on the students' occasion and learning objectives. Therefore, some experts have classified the kinds of learning strategies that can be applied by the students in order to assist their learning.

O'Malley and Chamot (1990) state there are three kinds of learning strategies. Those are metacognitive strategies, cognitive strategies, and socio-affective strategies. O'Malley continued to elaborate on the meaning of each strategy. 
1. Metacognitive strategies

According to O'Malley and Chamot (1990), metacognitive strategies consist of selfmonitoring, self-management, self-evaluation, directed attention, and organizational planning strategies.

Self-monitoring. It is correcting someone comprehension and accuracy in language task. For example, the students demand correction from their friends like pronunciation when performance in front of the class.

Self-management. It is controlling someone performance that assists students to accomplish the learning task. For example, the students try to manage their knowledge when a study in or outside the classroom.

Self-evaluation. It is checking someone progress and outcomes after the task has been completed. For example, the students evaluate their skills after speaking with the lecturer, friends also a native speaker.

Organizational planning. It is a strategy that helps students to organize the concept and ideas of the material in handling the next task of a language. For example, the students make a schedule to review the materials before the class began.

Directed attention. It is a strategy that assists the student to concentrate on the materials. For example, the students try to pay attention when their friends speak in the classroom.

\section{Cognitive Strategies}

Repetition. It is a strategy that helps students to imitate someone's speech through practice by their own self. For example, the students practice pronunciation repeatedly until perfect.

Resourcing. It is a strategy that focused on how students use a reference to gather information about the target language through the internet, textbooks, encyclopedia, and dictionaries. For example, students try to find out new words in the dictionary.

Grouping. The students classify the terminology, words, and concepts related to the material of language tasks based on meaning. For example, the students try to indicate the meaning of words then classify them into the same meaning and try to memorize the words.

Translation. The students use their mother tongue to understand in practicing a target language. For example, the students try to translate the sentences when someone speaks in front of the class.

Inferencing. The students used to try to predict the meanings of unfamiliar words and sentences related to language tasks. For example, the students think about the meaning of new vocabulary in order to find out the answer.

Deduction. The students try to understand and identify the rules of the target language. For example, the students try to find the pattern to correct sentences.

Summarizing. The students make a written summary of information related to the materials by using their own words. For example, the students write the main point of materials that had been explained by the lecturer.

Note-taking. This strategy helps students to write the keywords of the information in acquiring knowledge. For example, the students prepare a notebook to write the materials while the lecturer explained.

Keyword method. It is a strategy that helps students to remember the vocabulary of the target language by identifying the same meaning of familiar words and pronunciation in the first language. For example, when someone perform in front of the class, then he/she forget about the words, they try to find other words to explain the materials. 
Elaboration. This strategy focused on how the students connect the information or materials based on their experiences. For example, the students find more information and try to combine the ideas, then elaborate on the concept in their memory.

\section{Socio-affective strategies}

According to O' Malley and Chamot (1990), socio-affective strategies consist of questioning for clarification and cooperation strategies with others.

Questioning for clarification. This strategy helps students in asking for verification and asking for a correction. For example, the students ask her/his friend to correct their mistakes in pronouncing words before presentation in front of the class.

Cooperation. It is a strategy that helps students to cooperate with their friends to solve a problem in the learning activity. For example, the students discuss with their friends in a pair of groups to solve a problem.

\section{ENGLISH SPEAKING SKILL}

As one of the four main skills in English, speaking becomes an important skill in the teaching and learning process in the classroom. Speaking is an English skill that must be learned by the students. Speaking helps students to express their ideas to others. Furthermore, the term speaking in English teaching and learning process has been defined by some experts. According to Brown (2003), speaking is an oral communication between speakers and audiences that use to transfer information, ideas, and feelings. In the same way, Nunan (2003) defines speaking is an oral interaction of constructing systematic verbal utterances to deliver meaning. In short, it can be concluded that speaking is oral communication that use to share the speaker's ideas by using a language.

\section{SPEAKING ENGLISH FOR ACADEMIC IN ENGLISH DEPARTMENT}

For English Department students, academic speaking may be the most important skill that should be learned by them who, someday, will be an English teacher. It is because they are required to master the skill of delivering a presentation for academic purposes and professional forms in front of many people, especially their students, with English as the medium of communication.

Speaking for Academic is a subject that develops speaking skills using various activities and topics in basic communication competence. According to Dannels (2001), speaking for academic or educational purposes requires the students to deliver a presentation and to be able to facilitate a discussion. The topics and activities discuss the situation in academic context. This subject helps students to produce English utterances related to the various roles demanded in speech and communication activities. That is the reason for English Department of the State University of Gorontalo provides the subject for the students. Based on the syllabus of Universitas Negeri Gorontalo (2017), Speaking for Academic is a speaking class that gives a strong foundation for the students to enhance their skills and ability on public speaking. 


\section{LEARNING STRATEGIES IN ENGLISH SPEAKING SKILL}

Sometimes, students feel uneasy when they face any difficulty during their learning activities. They may lack competency and confidence in developing their ability and capability toward their studies. Therefore, it is necessary and important for them to find the appropriate tools or techniques that can help them in their learning. Such kinds of tools are called as learning strategies.

In addition, by using certain learning strategies, learners may improve their performance especially for those who are not well enough on their metacognitive skill. Furthermore, learning strategies that are used by the students will help them to increase their independence and engagement with their learning process.

In the learning process, students are hoping to have as many opportunities as possible to use multiple ways to acquire knowledge of the subject. These ways which are called as learning strategies will be indicated by the students 'activities and behaviors. National Research Council of Washington (1994) stated that what the students do and act in their learning activities show the learning strategies they use. In addition, learning strategies are important for the students' learning process because they stand as the tools for active and self-directed movement, which is essential for developing the students' communicative competence (Oxford, 1990). Moreover, learning strategies that are used by the students will help them to increase their independence and engagement with their learning process. Learning strategies facilitate the students to share their difficulties with the materials with their classmates as well as with their lecturer. However, learning strategies can be used for language skills such as speaking.

\section{RESEARCH METHOD METHODOLOGY OF RESEARCH}

This research was designed by applying a mixed method. Mix method is a method that used quantitative and qualitative to collect and analyze the data in a study (Creswell and Clark, 2011). In the same way, Denscombe (2008) as cited in Ente (2017: 23) state that mix method is an alternative technique that mixed qualitative and quantitative approach. Additionally, the fundamental of using mix method is to provide the answer to the research question clearly. Moreover, the researcher collected the data in the form of quantitative and elaborate the data collection with qualitative. By using quantitative, the researcher identified the frequency of kinds of learning strategies in the form of numerical and percentages, then it was clarified by using qualitative based on the information from the interview session.

\section{PARTICIPANTS}

The participants of this research were the students of class 2017 in English Department in the fourth semester. There are five classes of the fourth semester, with the number of students about 107 students. Nevertheless, the participants of this research were only those who had passed Speaking for General Communication and Speaking for Professional Context.

Furthermore, the questionnaire were distributed for 107 students and then the researcher recruited 5 students as the representative in the interview session. The researcher chose different students from each class based on their answers in the questionnaire. The participants were chosen in order to discover various views and opinions from the students based on their experiences in speaking class. 


\section{DATA COLLECTION AND ANALYSIS}

The data obtained from the questionnaire is used as the primary data. The researcher used a closed-ended question and Likert scale. Then, the results of students' responses were sorted in the frequency of occurrence (never, seldom, sometimes, often and always). In the questionnaire, the students were required to give mark $(\checkmark)$ in the question. In the question sheet, it contains students' identity, such as name, class, and gender. The questionnaire consisted of 19 numbers, which are separated into three types of learning strategies. The list of the questionnaire was adapted from Oxford, Rebbeca L. \& Nyikos, Martha (1989) and those have been modified by the researcher. In the questionnaires, the researcher provides some activities used by the students which are indicated the learning strategies. In conducting an interview session, the researcher provides the questions list in English and Indonesian which is aimed to facilitate the participants in order to answer the question comfortably. The participants have 4-6 minutes for the interview session. In this case, the instruments which are needed for the interview are audio recording and question list.

However, the steps of analyzing the data were: Classification, the researcher distributes the questionnaires to the students. After that, the researcher classifies the data based on the students' answers related to the research question. Then, the researcher Identifying, the result of the questionnaire related to the kinds of learning strategies by using descriptive percentages $\mathrm{P}=\mathrm{f} / \mathrm{n} \times 100 \%$. After that, the researcher Organizing, the data from questionnaires by grouping the answer based on the research question. Then, after checking the data transcript from the interview, the data transcript is organized by relating it with kinds of learning strategies. The last step is Reporting themes found within data, the researcher concludes the result of questionnaire and interview session, then the results are reported in the research findings.

\section{FINDINGS AND DISCUSSION FINDINGS}

This section provides a description and analysis of the findings from the study of strategy use by students in English Department of State University of Gorontalo. The data are presented according to the research questions.

\section{METACOGNITIVE STRATEGIES}

The results of metacognitive strategies showed the salient responses from the participants, which were always, often, and some time. Generally, most of the students always used selfmonitoring as their strategy. There were $46.7 \%$ of students preferred to use self-monitoring to help them learn the process which was indicated in number 2. Moreover, there were $37.3 \%$ who often used self- evaluation in the English speaking class which indicates in number 5 . While $41.1 \%$ of students sometimes used organizational planning as their strategy which was indicated in number 4. 
TABLE 1. The results of metacognitive strategies by students

\begin{tabular}{|c|c|c|c|c|c|c|}
\hline \multirow{2}{*}{ No } & \multirow[b]{2}{*}{ Learning Strategies } & \multicolumn{5}{|c|}{ Frequency } \\
\hline & & Never & Seldom & Sometimes & Often & Always \\
\hline 1 & $\begin{array}{l}\text { I try to find the } \\
\text { opportunities to speak } \\
\text { English with others as } \\
\text { much as possible }\end{array}$ & & & $34.5 \%$ & 23.3 & $42 \%$ \\
\hline 2 & $\begin{array}{l}\text { I notice my mistakes } \\
\text { in speaking English }\end{array}$ & & & $28.9 \%$ & 24.2 & $46.7 \%$ \\
\hline 3 & $\begin{array}{l}\text { I try to concentrate on } \\
\text { someone who speaks } \\
\text { English }\end{array}$ & & & $27.1 \%$ & 32.7 & $40.1 \%$ \\
\hline 4 & $\begin{array}{l}\text { I arrange my schedule } \\
\text { to improve my } \\
\text { speaking skill }\end{array}$ & & & $41.1 \%$ & 33.6 & $25.2 \%$ \\
\hline 5 & $\begin{array}{l}\text { I check my progress in } \\
\text { learning speaking and } \\
\text { try to evaluate myself }\end{array}$ & & & $26.1 \%$ & 37.3 & $36.4 \%$ \\
\hline
\end{tabular}

COGNITIVE STRATEGIES

According to O'Malley and Chamot (1990), cognitive strategies focused on transformation and manipulation of material or task. Repetition, resourcing, grouping, translation, inferencing, deduction, summarizing, note-taking, keyword method, and elaboration were examples of cognitive strategies. There were ten statements submitted in the questionnaire which provided the different activities based on the learning strategies.

According to the data above, the students gave varied responses. There were $51.4 \%$ of students who always used note taking in speaking class. It was indicated in number 8 . However, for other statements the responses varied, there were $41 \%$ of students who often used repetition strategy which was indicated by the learning strategy in number 1 . Further, in other statements, there were $47.6 \%$ of students who choose sometimes to use elaboration with the given statements in cognitive strategies. It was indicated in number 10. 
TABLE 2. The results of cognitive strategies by students

\begin{tabular}{|c|c|c|c|c|c|c|}
\hline \multirow{2}{*}{ No. } & \multirow{2}{*}{ Learning Strategies } & \multicolumn{5}{|c|}{ Frequency } \\
\hline & & Never & Seldom & Sometime & Often & Always \\
\hline 1 & $\begin{array}{l}\text { I try to practice my } \\
\text { speaking like Native } \\
\text { English speakers }\end{array}$ & & & $33.6 \%$ & $41 \%$ & $25.2 \%$ \\
\hline 2 & $\begin{array}{l}\text { I read English passage in } \\
\text { books or the internet to } \\
\text { acquire the material of } \\
\text { Speaking }\end{array}$ & & & $42 \%$ & $34.5 \%$ & $23.3 \%$ \\
\hline 3 & $\begin{array}{l}\text { I try to predict the } \\
\text { meaning of English } \\
\text { words in sentences and } \\
\text { divide it into parts that } \\
\text { are understandable }\end{array}$ & & & $41 \%$ & $36.4 \%$ & $22.4 \%$ \\
\hline 4 & $\begin{array}{l}\text { When I perform in the } \\
\text { classroom I use my } \\
\text { mother tongue if I forget } \\
\text { the vocabulary in English }\end{array}$ & & & $42.9 \%$ & $37.3 \%$ & $19.6 \%$ \\
\hline 5 & $\begin{array}{l}\text { If I do not know of an } \\
\text { English word, I use word } \\
\text { or phrase that means the } \\
\text { same thing }\end{array}$ & & & $25.2 \%$ & $33.6 \%$ & $41 \%$ \\
\hline 6 & $\begin{array}{l}\text { I try to listen to the } \\
\text { English speaker and } \\
\text { identify the English } \\
\text { Pattern }\end{array}$ & & & $43.9 \%$ & $34.5 \%$ & $21.4 \%$ \\
\hline 7 & $\begin{array}{l}\text { When I read or hear an } \\
\text { related to English, I } \\
\text { always make summaries }\end{array}$ & & & $26.1 \%$ & $32.7 \%$ & $41 \%$ \\
\hline 8 & $\begin{array}{l}\text { I try to write a new } \\
\text { vocabulary by making a } \\
\text { note in my book }\end{array}$ & & & $22.4 \%$ & $26.1 \%$ & $51.4 \%$ \\
\hline 9 & $\begin{array}{l}\text { I try to write a new } \\
\text { I remember new } \\
\text { vocabulary or phrase by } \\
\text { identifying a familiar }\end{array}$ & & & $25.2 \%$ & $32.7 \%$ & $42 \%$ \\
\hline 10 & $\begin{array}{l}\text { I try to elaborate on the } \\
\text { new information with } \\
\text { other concepts } \\
\text { I try to elaborate on the }\end{array}$ & & & $47.6 \%$ & $27.1 \%$ & $25.2 \%$ \\
\hline
\end{tabular}

Note. (adapted from Oxford, Rebbeca L. \& Nyikos, Martha (1989) 


\section{SOCIO-AFFECTIVE STRATEGIES}

According to O'Malley and Chamot (1990), a socio-affective strategy is a strategy that focused on social-meditating with others. Questioning for clarification, and cooperation were examples of socio-affective strategies. There were four statements submitted in the questionnaire which provided the different activities based on the learning strategies.

TABLE 3. The results of Socio-affective strategies by students

\begin{tabular}{|c|c|c|c|c|c|c|}
\hline \multirow{2}{*}{ No. } & \multirow{2}{*}{ Learning Strategies } & \multicolumn{5}{|c|}{ Frequency } \\
\hline & & Never & Seldom & Sometime & Often & Always \\
\hline 1 & $\begin{array}{l}\text { I ask someone to } \\
\text { speak slowly when I } \\
\text { cannot catch the } \\
\text { meaning of English } \\
\text { Sentences }\end{array}$ & & & $43.9 \%$ & $34.5 \%$ & $21.4 \%$ \\
\hline 2 & $\begin{array}{l}\text { I ask someone to } \\
\text { correct my mistake in } \\
\text { Speaking }\end{array}$ & & & $25.2 \%$ & $33.6 \%$ & $41 \%$ \\
\hline 3 & $\begin{array}{l}\text { If I do not understand } \\
\text { the materials, I ask } \\
\text { some question to my } \\
\text { friends }\end{array}$ & & & $39.2 \%$ & $35.5 \%$ & $25.2 \%$ \\
\hline 4 & $\begin{array}{l}\text { When I feel nervous } \\
\text { to speak English in } \\
\text { front of the class, } \\
\text { some of my friends } \\
\text { try to make me calm } \\
\text { Down }\end{array}$ & & & $24.2 \%$ & $27.1 \%$ & $48.5 \%$ \\
\hline
\end{tabular}

The results from the table reveal that generally, the students used learning strategies during the learning activities, such as in the fourth statement there were $48.5 \%$ students who always used cooperation to assist them in speaking class.

However, other statements the responses varied, such as in the first statement there were $43.9 \%$ students sometimes used questioning for clarification as to their learning strategies in English speaking class.

\section{DISCUSSION}

The most strategy that appears and used by students was note taking. It can be seen from the questionnaire data in cognitive strategies. There were $51.4 \%$ of students always used 
note taking as their strategy. The students used note taking when they were preparing some notes before coming to the class or write the information while listening to the lecturer and friends when they were doing a presentation in the classroom. So, it is to help students easy to understand the materials. Boyle and Weishaar (2001) stated that note-taking facilitates students to comprehend the material clearly by using their own words. Note-taking helps students to improve their skill by writing the simple words of the material.

Meanwhile, the least strategy that applied by the students is a translation. It can be seen from the questionnaire data. In that strategy, there was $19.6 \%$ used translation. For this reason, as a student in the fourth semester and learn academic speaking. The students must speak English while doing a presentation and they are not allowed to use their mother tongue. As stated by Bagheri and Fazel (2011) states that most of the students preferred applied translation in writing skills. Similarly, by Kasmer (1999) claims that translation should be in writing skill rather than speaking skill. Considering that the students cannot ask questions when the lecturer speak and explain the materials in English. As a result, the students do not understand the materials.

On the other hand, according to the data findings from questionnaires and interviews indicate that cooperation is the dominant strategy that is used by male students. In that strategy, there were $16.8 \%$ from $25.2 \%$ who choose socio-affective strategies. The reason for the male students applied cooperation because they have some difficulties when learning alone. So, they need others to give some advice to make them focused and confident when presenting the materials. This is related with Abrami, Poulsen \& Chambers (2004) as cited in (Alabeeke, Samuel \& Osaat) stated that cooperation help students working together with others in pair or group to get information and feedback in order to improve their learning.

Meanwhile, the most strategy used by female students is self-evaluation. It is shown in the questionnaire, there were $27.1 \%$ from $36.4 \%$ of students preferred used a metacognitive strategy which is a self-evaluation as their strategy in learning English speaking. the reason for female students used self-evaluation because they were better to manage and control their emotions than male students. So, female students tend to pay attention to their learning process. Also, the female students have more opportunity to explore and evaluate their capability in applying the learning strategies as well as their knowledge of the subject matter. This is supported by Zimmerman and Martinez-Pons (1990) as cited in Bozinovic and Sindik (2011) found that most female students apply selfevaluation strategies to plan and evaluate their learning process. It is because the female students would like to compare the knowledge and skill before and after they have learned.

\section{CONCLUSION AND RECOMENDATION}

\section{CONCLUSION}

Speaking is an English skill that must be learned by the students. Speaking helps students to express their ideas to others. This is correlated with Bygate (1991), in which he stated that speaking, as a skill, consists of two components which were production and interaction skill. As the production skill, the speakers can produce an oral production in various ways by facilitating themselves with certain devices that will help and ease their speaking, while as the interaction skill as a skill in which the speakers and the listeners should be good communicators by being good in conveying what they want to say which is understandable for their interlocutor. Therefore, it is necessary for the students to think of any idea or strategies to help them in learning English speaking.

Moreover, learning strategy is a strategy applied by the students to assist and help them in their learning activities. This is supported by Oxford (1990), learning strategies as 
some steps taken by students to enhance their own learning. Learning strategies were specific actions taken by the students to make their learning easier, faster, more enjoyable, more self-directed, more effective, and more transferable to new situations.

However, there were many ways for how students can apply learning strategies. Those learning strategies may be chosen depending on the students' occasion and learning objectives. Additionally, there were many kinds of learning strategies applied by students in English speaking class. In this research, English Department students used some learning strategies related to O'Malley and Chamot (1990). Those were metacognitive strategies, cognitive strategies, and socio-affective strategies. In each strategy consists of some subcategories.

\section{RECOMMENDATION}

First, for the students, this research helps students to gain information related to learning strategies that they may use in English speaking class. The students must choose the learning strategies that can support them to increase their speaking skills, especially in academic speaking.

Second, this research suggests for the lecturer to be aware that learning strategies are important for students to achieve a learning goal. It is necessary for the lecturer to realize that the students have different skills to catch and understand a lesson, so that they may use various learning strategies to acquire knowledge. For this reason, the lecturers should find the best technique of teaching in order to make the students more active in the classroom.

Third, this research suggests for the next researcher to conduct research-related to learning strategies with different theories in different skills, such as in writing, reading, and listening class. The future researcher will know that there were more than one learning strategies from different experts that can improve students' skills. In addition, it will be interesting for the next researcher to compare the learning strategies.

\section{REFERENCES}

Abrami, P. C., Poulsen, C., \& Chambres, B. (2004). Teacher motivation to implement an educational innovation: Factors differentiating users and non-users of cooperative learning. Educational Psychology, 24(2), 201216.

Alabekee, C. E., Samuel, A., Osaat, D, S. (2015). Effect of cooperative learning strategy on students learning experience and achievements in mathematics. International Journal of Education Learning and Development, 3(4), 66-67.

Askia, S., Manurung, K., \& Wahyudin. (2016). Improving speaking skillls through active learning strategy of the year eight students. E-Journal of English Language Teaching Society (ELTS), 4(2), 1.

Bagheri, M. S., \& Fazel, I. (2011). EFL learners beliefs about translation and its use as a strategy in writing. Reading Matrix: An International Online Journal. 3(4).

Boyle, J. R., \& Weishaar, M. (2001). The effect of strategic note-taking on the recall and reading comprehension of lecture infromation for high school students with learning disabilities. Learning Disabilities Research \& Practice, 16(3), 133-141).

Bozinovic. N., \& Sindik, J. (2011). Gender differences in the use of learning strategies in adult foreign language learners. Metodicki Obzori 6, 11-12.

Brown, H. Douglas. (2003). Language assessment: Principle and classroom practices. New York: Pearson Education Inc.

Bygate, M. (1991). Speaking. Oxford: Oxford University Press.

Creswell, J. W., \& Clark P, V. L. (2011). Designing and conducting mixed methods Research (2nd ed). Thousand Oakd, CA: Sage Publications, Inc. Retrieved from https://libro.eb.20.net

Dannels, D. P. (2011). Time to speak up: A theoretical framework of situated pedagogy and practice for communication across the curriculum. Communication Education 2, 50.

Denscombe, M. (2008). Communities of practice: A research paradigm for the mix methods apporach. Journal of Mixed Methods Research, 2(3), pp. 270-283. 
Ente, , R. M. (2017). Fluency and some obstacles in speaking English. (Undergraduate Thesis). Universitas Negeri Gorontalo, Indonesia.

Faculty of Letters and Culture. (2017). Semester lesson plan for English Department of UNG. Gorontalo: State University of Gorontalo.

Juwita, R., Sukirlan, M., Kadaryanto, B. (2015). Correlation between students' learning strategies and their speaking skill at High School.

Kasmer, W. (199). The role of translation in the EFL/ESL classroom. University of Birmingham, UK.

National Research Council. (1994). Learning, remembering, believing. Washington, DC: National Academy Press.

Nunan, David. (2003). Practical english language teaching. New York: McGraw-Hill.

O’Malley, J Michael \& Anna Uhl Chamot (1990). Learning strategies in second language acquisition. Cambridge: Cambridge University Press. Retrieved from https://books.google.co.id/books?id

Oxford, R. L. (1990). Language learning strategies: What every teacher should know. Baston, Massachusetts: Heinle \& Heinle Publisher.

Oxford, R. L., \& Nyikos, M. (1989). Variables affecting choice of language learning strategies by university students. The Modern Language Journal, 73, iii, 291-300.

Reid, Gavin. (2005). Learning styles and inclusion. London: Paul Chapman Publishing.

Rigney, J. W. (1978). Learning strategies: A theoretical perspective. HFO'Neil (Jr) 165-205.

Rubin, J. (1975). What the "Good language learner" can teach us. TESOL Quarterly, 9(1), 41- 51.

Zimmerman, B. J., \& Martinez-Pons, M. (1990). Student differences in self-regulated learning: Relating grade, sex, and giftedness to self-efficacy and strategy use. Journal of Educational Psychology, 82(1), 51-59. 